\title{
Sex Differences in Blood Pressure of Aged Ren-2 Transgenic Rats
}

\author{
Hana RAUCHOVÁ ${ }^{1}$, Silvie HOJNÁ ${ }^{1}$, Michaela KADLECOVÁ ${ }^{1}$, Ivana VANĚČKOVÁ ${ }^{1}$, \\ Josef ZICHA ${ }^{1}$
}

${ }^{1}$ Institute of Physiology of the Czech Academy of Sciences, Prague, Czech Republic

Received November 14, 2019

Accepted January 16, 2020

Epub Ahead of Print March 23, 2020

\section{Summary}

Sex-related differences were observed not only in human but also in experimental hypertension. The aim of our study was to compare blood pressure (BP) of aged male and female heterozygous transgenic rats (TGR) harboring Ren-2 mouse gene, with their normotensive Hannover Sprague-Dawley (HanSD) controls. At the age of 9 months, systolic (SBP) and diastolic blood pressure (DBP) were measured by a direct puncture of carotid artery in rats awaking from isoflurane anesthesia. Thiobarbituric acid-reactive species (TBARS) formation was monitored as indicator of lipid peroxidation damage in heart, kidney and liver, whereas intracellular content of reduced glutathione was determined in the same organs as the main intracellular antioxidant. Furthermore, plasma triglycerides and total cholesterol as well as high-density lipoprotein (HDL) and low-density lipoprotein (LDL) fractions of cholesterol were measured. As compared to HanSD rats, we found significantly elevated BP only in male TGR (MAP: $123 \pm 1$ vs. $171 \pm 5$, SBP: $150 \pm 2$ vs. $208 \pm 7$, and DBP: $99 \pm 3$ vs. $140 \pm 4 \mathrm{~mm} \mathrm{Hg}$ ), but not between TGR and HanSD females, which were both normotensive. We also did not find any significant differences in TBARS and reduced glutathione in the three above mentioned organs as well as in plasma cholesterol or its $\mathrm{HDL}$ and LDL fractions between transgene-negative HanSD and TGR animals of either sex. However, we found significant sex differences in TBARS, glutathione and plasma lipids in both rat strains. Our results confirmed that aged TGR exhibit a marked sexual BP dimorphism, which does not seem to be dependent on oxidative stress or abnormal cholesterol metabolism.

\section{Key words}

Hypertension - Thiobarbituric acid-reactive species (TBARS) • Reduced glutathione • Total plasma cholesterol $\bullet \mathrm{HDL}$ and LDL cholesterol fractions

\section{Corresponding author}

Hana Rauchová, Institute of Physiology, Czech Academy of Sciences, Vídeňská 1083, 14220 Praha 4, Czech Republic. E-mail: Hana.Rauchova@fgu.cas.cz

\section{Introduction}

Over the years plenty of data on blood pressure (BP) has been gathered in men and women. Generally, aging is usually associated with an increase in BP and hypertension becomes the most common chronic disease in the world. Men have higher incidence of hypertension compared with age-matched women until the onset of menopause. Prominent sex-related differences in hypertension were observed repeatedly not only in humans but also in experimental animals such as dog, rabbit, mouse or rat and even in birds (Blank et al. 2016, Lerman et al. 2019, Sandberg and Ji 2012). Animal models are inevitable for both the understanding hypertension pathogenesis and possible novel treatment options. Rats are often used as hypertension animal model. There are several rat models in which sex differences in BP were described - genetic hypertension in spontaneously hypertensive rats (Maris et al. 2005), NO-deficient hypertension induced by chronic L-NAME administration (Sainz et al. 2004) or salt hypertension in salt-sensitive Dahl rats (Zicha et al. 2012). There is an interesting model of hypertension in transgenic Ren-2 rats (TGR), in which mouse Ren-2 renin gene was inserted into the genome of normotensive Hannover Sprague-Dawley rats (HanSD). The overexpression of mouse renin gene induces the development of angiotensin II-dependent hypertension with endogenous activation of renin-angiotensin system (RAS), which plays a central 
role in blood pressure control and its long-term dysregulation causes sustained BP elevation. Therefore, the pharmacological RAS targeting is widely used in the clinical hypertension treatment and permanently tested in different experimental trials (Laurent 2017).

For a better understanding on the role of RAS in the pathogenesis of hypertension we can use TGR as a well-defined monogenetic model of hypertension (Mullins et al. 1990). Homozygous TGR display severe malignant hypertension accompanied by organ damage and they die at 7-13 weeks of age (Vernerová et al. 2009). On the other hand, heterozygous TGR develop a less severe hypertension, which allows long-term studies (Vaněčková et al. 2011). It was described that the established hypertension in male TGR is maintained or only a slight BP decrease occurs in the late adulthood (Lee et al. 1998, Springate et al. 1992, Vaněčková et al. 2011). In contrast, BP decline in female TGR can even yield normotensive values (Cargnelli et al. 1998, Lee et al. 1998, Vaněčková et al. 2011).

The aim of our study was to search for sex differences a) in blood pressure of 9-month-old male and female TGR, b) in the content of TBARS (oxidative stress marker) or reduced glutathione (intracellular antioxidant) in heart, kidney and liver, and c) in plasma lipids (triglycerides and cholesterol).

\section{Material and Methods}

\section{Animals}

Adult male and female heterozygous (mRen-2) 27 transgenic rats (TGR) aged 9 months were housed at $23{ }^{\circ} \mathrm{C}$ under a $12 \mathrm{~h}$ light/dark cycle periods, fed a standard rat chow Altromin and given to tap water ad libitum. Transgene-negative Hannover SpragueDawley rats (HanDS) served as controls. At the end of the experiment blood pressure was measured. After blood collection, kidney, heart and liver were excised and used for tissue analysis. Plasma samples (in the EDTA presence) were prepared and stored at $-80{ }^{\circ} \mathrm{C}$ until further analysis.

All the procedures and experimental protocols were performed in accordance with guidelines and practice established by the Ethical Committee of the Institute of Physiology CAS, conformed to the European Convention on Animal Protection and Guidelines on Research Animal Use.

\section{Measurement of blood pressure}

Mean arterial (MAP), systolic (SBP) and diastolic (DBP) blood pressure and heart rate were measured by a direct puncture of carotid artery under isoflurane anesthesia (2.5\% isoflurane) and in awaking animals $(0.5 \%$ isoflurane $)$. To eliminate the influence of circadian blood pressure (BP) variation, the measurements were always done approximately at the same time of day (between 8:00 and 10:00 a.m.).

\section{Determination of thiol concentration}

The intracellular content of reduced glutathione (GSH) in heart, kidney and liver was determined immediately in fresh tissues according to the methods described earlier (Ellman 1959). Briefly, the tissue samples were homogenized in $3 \%$ sulfosalicylic acid and $10 \%$ homogenates were centrifuged for $10 \mathrm{~min}$ at $3000 \mathrm{~g}$. A portion of the supernatant was mixed with $0.02 \mathrm{M} \mathrm{5,5}$ '-dithiobis-(2-nitrobenzoic acid) in $0.1 \mathrm{M}$ phosphate buffer ( $\mathrm{pH} 8)$. The absorbance of a colored product was read at $412 \mathrm{~nm}$, the concentration of GSH was calculated from calibration curve prepared by serial dilution of $1 \mathrm{mM}$ stock solution. The results were expressed as $\mu \mathrm{mol} \mathrm{GSH} / \mathrm{g}$ tissue.

\section{Measurement of lipid peroxidation}

Lipid peroxidation in the samples was monitored by measuring thiobarbituric acid-reactive substances (TBARS) formation (Ohkawa et al. 1979). The frozenthawed $10 \%$ homogenates were incubated with thiobarbituric and acetic acid at $95{ }^{\circ} \mathrm{C}$ for $45 \mathrm{~min}$. Absorbance was measured at $535 \mathrm{~nm}$ using Tecan Infinite M200 multimode microplate spectrofluorometer. The results were expressed as nmol of TBARS/mg of protein.

\section{Biochemical parameters}

Folin method was used for the determination of protein concentration using bovine serum albumin as standard (Lowry et al. 1951).

The concentrations of plasma triglycerides (TG), total cholesterol (TC), and high-density lipoproteincholesterol (HDL) were estimated using commercial kits (Pliva-Lachema Diagnostika, Brno, Czech Republic). Low-density lipoprotein-cholesterol (LDL) was estimated indirectly using the formula: $\mathrm{LDL}=\mathrm{TC}-(\mathrm{TG} / 5)$ - HDL.

\section{Results}

Figure 1 shows systolic (SBP), mean arterial (MAP) and diastolic (DBP) blood pressures in 9-monthold male and female TGR and their HanSD controls which were recorded in awaking animals. In TGR 

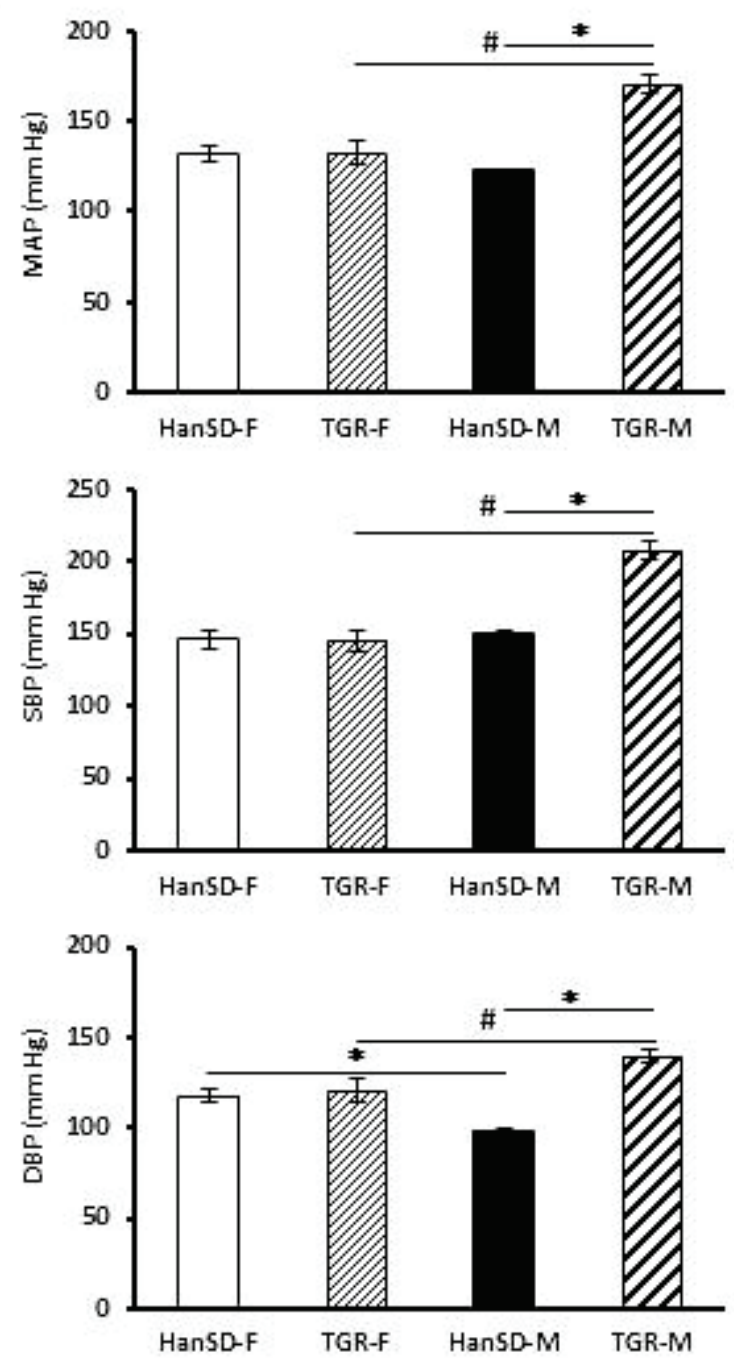

Fig. 1. Mean (MAP), systolic (SBP) and diastolic (DBP) blood pressure in awaking female (F) and male (M) Hannover SpragueDawley (HanSD) and transgenic rats (TGR) aged 9 months. All values are mean \pm SEM. Significantly different: $* P \leq 0.05$ vs. HanSD, ${ }^{\#} P \leq 0.05$ vs. females.

females, the blood pressures were decreased to normotensive values seen in HanSD females. On the other hand, older TGR males had still a considerable hypertension, their SBP and DBP being substantially elevated compared to their HanSD controls.

Body weights were higher in male but not in female TGR as compared to sex-matched HanSD animals (Table 1). The absolute weights of hearts and kidneys were always greater in males than in females of both genotypes, but there were no significant differences in the relative weights of hearts and kidneys between TGR and their sex- and age-matched HanSD controls. Similarly, 9-month-old male TGR had greater absolute liver weight than HanSD rats, but their relative liver weight was not increased.
To evaluate the degree of organ damage by lipid peroxidation we measured TBARS concentrations as an indirect marker of lipid peroxidation in the heart, kidney and liver (Table 2). We did not find any significant difference in TBARS concentrations in the particular tissues between HanSD and TGR rats, but we found significantly lower TBARS concentrations in all examined organs of male rats, irrespective of the genotype.

We observed the lowest concentration of thiol groups in the heart and the highest one in the liver (Table 3). Concentrations of thiol groups were not significantly different between TGR and HanSD animals. However, male rats of both genotypes had significantly higher heart and liver $\mathrm{SH}$ concentration but a significantly lower kidney $\mathrm{SH}$ concentration than corresponding females.

Male rats of both genotypes had significantly higher values of serum triglycerides (TG), total cholesterol (TC) and low-density lipoprotein-cholesterol (LDL) as well as the ratio between total cholesterol and its HDL fraction (TC/HDL, atherogenic index) than corresponding females (Table 4). However, there were no significant differences in the above parameters between TGR and HanSD controls.

\section{Discussion}

TGR represents a model of hypertension with a well-defined genetic background. We confirmed a marked sexual dimorphism in this model because our data obtained in awaking rats indicated BP elevation only in TGR males, whereas BP of TGR females was close to that of HanSD females. Sex-related differences in BP values were reported earlier in this strain. Our SBP values correspond well with previous two long-term studies (lasting 10-12 months) that followed both male and female TGR in comparison with their sex- and age-matched HanSD controls (Lee et al. 1996, Vaněčková et al. 2011). In both mentioned studies maximal SBP values were higher and the phase of established hypertension was longer in males than females. Cargnelli et al. (1998) showed that the established period of hypertension was followed by a progressive decrease of SBP towards the normal values in 35-week-old heterozygous females TGR, while SBP values of HanSD females were unaffected by ageing. Springate et al. (1994) described diminished SBP in 8-month-old male TGR compared to 2- and 4-month-old 
Table 1. General characteristics of female and male Hannover Sprague-Dawley (HanSD) and transgenic rats (TGR) aged 9 months.

\begin{tabular}{|c|c|c|}
\hline Females & $\operatorname{HanSD}(n=8)$ & TGR $(n=8)$ \\
\hline Body weight $(B W ; g)$ & $353 \pm 12$ & $382 \pm 8$ \\
\hline Heart weight $(H W ; m g)$ & $1165 \pm 24$ & $1253 \pm 24$ \\
\hline Relative heart weight $(H W / B W ; m g / g$ & $3.33 \pm 0.12$ & $3.31 \pm 0.13$ \\
\hline Kidney weight $(K W ; m g)$ & $2071 \pm 46$ & $2272 \pm 46^{*}$ \\
\hline Relative kidney weight (KW/BW; $\mathrm{mg} / \mathrm{g})$ & $5.93 \pm 0.29$ & $5.97 \pm 0.31$ \\
\hline Males & $\operatorname{HanSD}(n=6)$ & $\operatorname{TGR}(n=5)$ \\
\hline Body weight $(B W ; g)$ & $690 \pm 1^{\#}$ & $818 \pm 24^{* \#}$ \\
\hline Heart weight $(H W ; m g)$ & $1756 \pm 21^{\#}$ & $2130 \pm 55^{* \#}$ \\
\hline Relative heart weight $(H W / B W ; \mathrm{mg} / g$ & $2.55 \pm 0.03^{\#}$ & $2.61 \pm 0.09^{\#}$ \\
\hline Left ventricular weight (LVW; mg) & $1376 \pm 34$ & $1720 \pm 89^{*}$ \\
\hline Relative left ventricular weight ( $L V W / B W ; \mathrm{mg} / \mathrm{g})$ & $2.00 \pm 0.02$ & $2.12 \pm 0.06$ \\
\hline Kidney weight $(K W ; m g)$ & $4289 \pm 227^{\#}$ & $4762 \pm 212^{\#}$ \\
\hline Relative kidney weight (KW/BW; $\mathrm{mg} / \mathrm{g})$ & $6.22 \pm 0.34$ & $5.83 \pm 0.26$ \\
\hline Liver weight $(L W ; m g)$ & $23757 \pm 1921$ & $28376 \pm 2163^{*}$ \\
\hline Relative liver weight $(L W / B W ; m g / g)$ & $34.5 \pm 2.9$ & $34.7 \pm 2.3$ \\
\hline
\end{tabular}

All values are mean $\pm \mathrm{SEM}, \mathrm{n}$, number of animals is given in parentheses. Significantly different: $* P \leq 0.05$ vs. HanSD, ${ }^{*} P \leq 0.05$ vs. females.

Table 2. Thiobarbituric acid-reactive substances in heart, kidney and liver of female and male Hannover Sprague-Dawley (HanSD) and transgenic rats (TGR) aged 9 months.

\begin{tabular}{lcc}
\hline Females & HanSD $(\mathrm{n}=8)$ & TGR $(\mathrm{n}=8)$ \\
\hline Heart $(\mu \mathrm{mol} / \mathrm{mg}$ protein) & $15.93 \pm 0.90$ & $15.98 \pm 1.01$ \\
Kidney ( $\mu \mathrm{mol} / \mathrm{mg}$ protein) & $28.79 \pm 2.20$ & $28.96 \pm 1.34$ \\
Liver $(\mu \mathrm{mol} / \mathrm{mg}$ protein) & $13.46 \pm 0.98$ & $15.13 \pm 1.77$ \\
\hline Males & HanSD $(\mathrm{n}=6)$ & TGR $(\mathrm{n}=5)$ \\
\hline Heart $(\mu \mathrm{mol} / \mathrm{mg}$ protein) & $11.70 \pm 1.52^{\#}$ & $11.74 \pm 1.23^{\#}$ \\
Kidney $(\mu \mathrm{mol} / \mathrm{mg}$ protein) & $18.55 \pm 0.11^{\#}$ & $20.36 \pm 1.21^{\#}$ \\
Liver $(\mu \mathrm{mol} / \mathrm{mg}$ protein) & $8.80 \pm 0.45^{\#}$ & $8.52 \pm 2.19^{\#}$ \\
\hline
\end{tabular}

All values are mean $\pm \mathrm{SEM}, \mathrm{n}$, number of animals is given in parentheses Significantly different: ${ }^{*} P \leq 0.05$ vs. females.

rats of this strain. We extended our study by measuring of MAP and DBP in two different conditions, i.e. under deep isoflurane anesthesia (data not shown) and in animals awaking from this anesthesia. The differences in BP were more pronounced in awaking animals.

TGR with elevated endogenous angiotensin II were sporadically described as a suitable model of spontaneous liver fibrosis and portal hypertension (non- alcoholic fatty liver disease), which is associated with hepatic mitochondrial oxidative damage and impaired mitochondrial fatty acid oxidation (Klein et al. 2019, Wei et al. 2008, 2009). However, our group of aged TGR males showed neither the higher relative liver weight nor the increased level of TBARS in liver.

Oxidative or nitrosative stress, which represents the imbalance between production and elimination of 
Table 3. Concentration of thiol groups in heart, kidney and liver of female and male Hannover Sprague-Dawley (HanSD) and transgenic rats (TGR) aged 9 months.

\begin{tabular}{lcc}
\hline Females & HanSD $(\mathrm{n}=8)$ & TGR $(\mathrm{n}=8)$ \\
\hline Heart $(\mu \mathrm{mol} / \mathrm{g})$ & $1.73 \pm 0.08$ & $1.54 \pm 0.05$ \\
Kidney $(\mu \mathrm{mol} / \mathrm{g})$ & $4.10 \pm 0.17$ & $4.24 \pm 0.17$ \\
Liver $(\mu \mathrm{mol} / \mathrm{g})$ & $4.89 \pm 0.39$ & $4.82 \pm 0.28$ \\
\hline Males & HanSD $(\mathrm{n}=6)$ & TGR $(\mathrm{n}=5)$ \\
\hline Heart $(\mu \mathrm{mol} / \mathrm{g})$ & $2.13 \pm 0.08^{\#}$ & $2.35 \pm 0.05^{\#}$ \\
Kidney $(\mu \mathrm{mol} / \mathrm{g})$ & $3.19 \pm 0.18^{\#}$ & $3.36 \pm 0.15^{\#}$ \\
Liver $(\mu \mathrm{mol} / \mathrm{g})$ & $8.58 \pm 0.29^{\#}$ & $8.52 \pm 2.19^{\#}$ \\
\hline
\end{tabular}

All values are mean \pm SEM, $n$, number of animals is given in parentheses. Significantly different: ${ }^{\#} P \leq 0.05$ vs. females.

Table 4. Plasma lipids in female and male Hannover Sprague-Dawley (HanSD) and transgenic rats (TGR) aged 9 months.

\begin{tabular}{lcc}
\hline Females & HanSD $(\mathrm{n}=8)$ & TGR $(\mathrm{n}=8)$ \\
\hline Triglycerides $(\mathrm{mmol} / \mathrm{l})$ & $0.26 \pm 0.01$ & $0.26 \pm 0.03$ \\
Total cholesterol $(\mathrm{mmol} / \mathrm{l})$ & $1.96 \pm 0.14$ & $1.84 \pm 0.10$ \\
HDL $(\mathrm{mmol} / \mathrm{l})$ & $1.49 \pm 0.15$ & $1.44 \pm 0.08$ \\
LDL $(\mathrm{mmol} / \mathrm{l})$ & $0.42 \pm 0.09$ & $0.35 \pm 0.04$ \\
TC/HDL ratio & $1.36 \pm 0.11$ & $1.28 \pm 0.03$ \\
\hline Males & HanSD $(\mathrm{n}=6)$ & TGR $(\mathrm{n}=5)$ \\
\hline Triglycerides $(\mathrm{mmol} / \mathrm{l})$ & $0.85 \pm 0.06^{\#}$ & $0.79 \pm 0.15^{\#}$ \\
Total cholesterol $(\mathrm{mmol} / \mathrm{l})$ & $2.37 \pm 0.08^{\#}$ & $2.59 \pm 0.18^{\#}$ \\
HDL $($ mmol/l) & $1.28 \pm 0.03$ & $1.37 \pm 0.12$ \\
LDL (mmol/l) & $0.91 \pm 0.04^{\#}$ & $1.06 \pm 0.13^{\#}$ \\
TC/HDL ratio & $1.84 \pm 0.02^{\#}$ & $1.91 \pm 0.12^{\#}$ \\
\hline
\end{tabular}

All values are mean $\pm \mathrm{SEM}, \mathrm{n}$, number of animals is given in parentheses. Significantly different: ${ }^{*} P \leq 0.05$ vs. females. HDL, highdensity lipoprotein-cholesterol; LDL, low-density lipoprotein-cholesterol; TC, total cholesterol

reactive oxygen or nitrogen species, is often considered as an important factor contributing to the pathogenesis of different forms of hypertension (Guzik and Touyz 2017, Reckelhoff et al. 2019). To examine the role of oxidative damage, we measured TBARS levels in three different organs (liver, heart and kidney). Vokurková et al. (2015) disclosed higher concentration of TBARS in renal cortex in 3-month-old TGR males but this difference was not confirmed by the parallel measurements of conjugated dienes or oxidative index. However, we did not find significant differences in renal, cardiac or liver levels of TBARS between TGR and HanSD rats of either sex. Kopkan et al. (2009) reported increased levels of malondialdehyde in the whole kidney and left heart ventricle of 3-month-old male TGR and significantly reduced levels of malondialdehyde after the chronic administration of $\mathrm{O}_{2}^{-}$scavenger tempol or NADPH oxidase inhibitor apocynin but this malondialdehyde decrease was not associated with any SBP change. Interestingly, in spite of higher blood pressure in our TGR males we found significantly lower concentrations of TBARS than in females for which we cannot offer a plausible explanation.

The main intracellular antioxidant reduced glutathione (GSH) plays important roles in peroxide detoxification, recycling of vitamins $\mathrm{C}$ and $\mathrm{E}$, cysteine 
storage and other biochemical reactions (Aquilano et al. 2014, Gould and Pazdro 2019). We found sex-different GSH concentrations in all examined tissues (heart, kidney, liver). Males had always higher GHS concentrations in heart and liver but lower values in the kidney. On the other hand, GSH concentrations were not influenced by rat genotype. Similar GSH concentrations were also obtained in 3-month-old TGR males (Vokurková et al. 2015b) and 5-month-old Dahl males (Vokurková et al. 2015a).

All parameters of lipid metabolism (with the exception of HDL cholesterol) were significantly higher in older males than females. This is a rather surprising finding because there are several reports of higher plasma cholesterol levels in female than male Sprague Dawley or Lewis rats of various age (Lee et al. 2008, Borbélyová et al. 2017). On the other hand, there were no differences between HanSD and TGR animals of either sex. To our knowledge, there are no data on alterations of lipid metabolism in TGR. The only relevant study (Vettor et al. 1994) reported similar fasting levels of plasma triglycerides in TGR and HanSD rats aged 5 months.

In summary, the present study shows a sexual dimorphism in blood pressure of heterozygous TGR. Additionally, we did not find any corresponding difference in TBARS concentrations and reduced glutathione levels between transgene-negative normotensive (HanSD) and hypertensive Ren-2 transgenic rats (TGR).

\section{Conflict of Interest}

There is no conflict of interest.

\section{Acknowledgements}

The study was supported by an international research grant GACR 19-08260J and by an institutional support (RV0:67985823). A part of research results was presented on FEPS meeting in Bologna, Italy (Rauchová et al. 2019).

\section{References}

AQUILANO K, BALDELLI S, CIRIOLO MR: Glutathione: new roles in redox signaling for an old antioxidant. Front Pharmacol 5: 196, 2014. https://doi.org/10.3389/fphar.2014.00196

BLENCK CL, HARVEY PA, RECKELHOFF JF, LEINWAND LA: The importance of biological sex and estrogen in rodent models of cardiovascular health and disease. Circ Res 118: 1294-1312, 2016. https://doi.org/10.1161/CIRCRESAHA.116.307509

BORBÉlYOVÁ V, DOMONKOS E, BÁBÍČKOVÁ J, TÓTHOVÁ L, KAČMÁROVÁ M, ULIČNÁ O, OSTATNÍKOVÁ D, HODOSY J, CELEC P: Does long-term androgen deficiency lead to metabolic syndrome in middle-aged rats? Exp Gerontol 98: 38-46, 2017. https://doi.org/10.1016/j.exger.2017.08.016

CARGNELLI G, ROSSI GP, PESSINA AC, LUCIANI S, DEBETTO P, GANTEN D, PETERS J, BOVA S: Changes of blood pressure and aortic strip contractile responses to ET-1 of heterozygous female transgenic rats, TGR(mRen2)27. Pharmacol Res 37: 207-211, 1998. https://doi.org/10.1006/phrs.1998.0287

ELLMAN GL: Tissue sulfhydryl groups. Arch Biochem Biophys 82: 70-77, 1959. https://doi.org/10.1016/00039861(59)90090-6

FORTEPIANI LA, RECKELHOFF JF: Role of oxidative stress in the sex differences in blood pressure in spontaneously hypertensive rats. J Hypertens 23: 801-805, 2005. https://doi.org/10.1097/01.hjh.0000163149.05083.13

GOULD RL, PAZDRO R: Impact of supplementary amino acids, micronutrients, and overall diet on glutathione homeostasis. Nutrients 11: 1056, 2019. https://doi.org/10.3390/nu11051056

GUZIK TJ, TOUYZ RM: Oxidative stress, inflammation, and vascular aging in hypertension. Hypertension 70: 660-667, 2017. https://doi.org/10.1161/HYPERTENSIONAHA.117.07802

KASPER SO, CARTER CS, FERRARIO CM, GANTEN D, FERDER LF, SONNTAG WE, GALLAGHER PE, DIZ DI: Growth, metabolism, and blood pressure disturbances during aging in transgenic rats with altered brain $\begin{array}{lllll}\text { renin-angiotensin } & \text { systems. } & \text { Physiol } & \text { Genomics }\end{array}$ https://doi.org/10.1152/physiolgenomics.00163.2005 
KLEIN S, KLEINE CE, PIEPER A, GRANZOW M, GAUTSCH S, HIMMIT M, KAHRMANN K, SCHIERWAGEN R, USCHNER FE, MAGDALENO F, NAOUM ME, KRISTIANSEN G, WALTHER T, BADER M, SAUERBRUCH T, TREBICKA J: TGR(mREN2)27 rats develop non-alcoholic fatty liver disease-associated portal hypertension responsive to modulations of Janus-kinase 2 and Mas receptor. Sci Rep 9: 11598, 2019. https://doi.org/10.1038/s41598-019-48024-4

KOPKAN L, HUSKOVÁ Z, VAŇOURKOVÁ Z, THƯMOVÁ M, ŠKAROUPKOVÁ P, MALÝ J, KRAMER HJ, DVOŘÁK P, ČERVENKA L: Reduction of oxidative stress does not attenuate the development of angiotensin II-dependent hypertension in Ren-2 transgenic rats. Vascul Pharmacol 51: 175-181, 2009. https://doi.org/10.1016/j.vph.2009.06.001

LAURENT S: Antihypertensive drugs. Pharmacol Res 124: 116-125, 2017. https://doi.org/10.1016/j.phrs.2017.07.026

LEE CE, KANG JS, KIM KI: Effects of gender, gonadectomy and sex hormones on growth and plasma cholesterol level in rats. Ann Nutr Metab 53: 1-5, 2008. https://doi.org/10.1159/000152867

LEE MA, BÖHM M, PAUL M, BADER M, GANTEN U, GANTEN D: Physiological characterization of the hypertensive transgenic rat TGR(mREN2)27. Am J Physiol 270: E919-E929, 1996. https://doi.org/10.1152/ajpendo.1996.270.6.E919

LERMAN LO, KURTZ TW, TOUYZ RM, ELLISON DH, CHADE AR, CROWLEY SD, MATTSON DL, MULLINS JJ, OSBORN J, EIRIN A, RECKELHOFF JF, IADECOLA C, COFFMAN TM: Animal models of hypertension: A scientific statement from the American Heart Association. Hypertension 73: e87-e120, 2019. https://doi.org/10.1161/HYP.0000000000000090

LOWRY OH, ROSEBROUGH NJ, FARR AL, RANDALL RJ: Protein measurement with the Folin phenol reagent. J Biol Chem 193: 265-275, 1951.

MARIS ME, MELCHERT RB, JOSEPH J, KENNEDY RH: Gender differences in blood pressure and heart rate in spontaneously hypertensive and Wistar-Kyoto rats. Clin Exp Pharmacol Physiol 32: 35-39, 2005. https://doi.org/10.1111/j.1440-1681.2005.04156.x

MULLINS JJ, PETERS J, GANTEN D: Fulminant hypertension in transgenic rats harbouring the mouse Ren-2 gene. Nature 344: 541-544, 1990. https://doi.org/10.1038/344541a0

NAUTIYAL M, KATAKAM PV, BUSIJA DW, GALLAGHER PE, TALLANT EA, CHAPPELL MC, DIZ DI: Differences in oxidative stress status and expression of MKP-1 in dorsal medulla of transgenic rats with altered brain renin-angiotensin system. Am J Physiol Regul Integr Comp Physiol 303: R799-R806, 2012. https://doi.org/10.1152/ajpregu.00566.2011

OHKAWA H, OHISHI N, YAGI K: Assay for lipid peroxides in animal tissues by thiobarbituric acid reaction. Anal Biochem 95: 351-358, 1979. https://doi.org/10.1016/0003-2697(79)90738-3

RAUCHOVÁ H, HOJNÁ S, KADLECOVÁ M, VANĚČKOVÁ I, ZICHA J: Sex-related differences of blood pressure in older Ren-2 transgenic rats. Acta Physiol 227 (Suppl 718): 173, 2019.

RECKELHOFF JF, ROMERO DG, YANES CARDOZO LL: Sex, oxidative stress, and hypertension: insights from animal models. Physiology (Bethesda) 34: 178-188, 2019. https://doi.org/10.1152/physiol.00035.2018

SÁINZ J, OSUNA A, WANGENSTEEN R, DE DIOS LUNA J, RODRÍGUEZ-GÓMEZ I, DUARTE J, MORENO JM, VARGAS F: Role of sex, gonadectomy and sex hormones in the development of nitric oxide inhibitioninduced hypertension. Exp Physiol 89:155-162, 2004. https://doi.org/10.1113/expphysiol.2003.002652

SANDBERG K, JI H: Sex differences in primary hypertension. Biol Sex Differ 3: 7, 2012. https://doi.org/10.1186/2042-6410-3-7

SPRINGATE JE, FELD LG, GANTEN D: Renal function in hypertensive rats transgenic for mouse renin gene. Am J Physiol 266: F731-F737, 1994. https://doi.org/10.1152/ajprenal.1994.266.5.F731

VANĚČKOVÁ I, HUSKOVÁ Z, VAŇOURKOVÁ Z, ČERVENKA L: Castration has antihypertensive and organoprotective effects in male but not in female heterozygous Ren-2 rats. Kidney Blood Press Res 34: 46-52, 2011. https://doi.org/10.1159/000322618

VERNEROVÁ Z, KUJAL P, KRAMER HJ, BÄCKER A, ČERVENKA L, VANĚČKOVÁ I: End-organ damage in hypertensive transgenic Ren-2 rats: influence of early and late endothelin receptor blockade. Physiol Res 58 (Suppl 2): S69-S78, 2009. 
VETTOR R, CUSIN I, GANTEN D, ROHNER-JEANRENAUD F, FERRANNINI E, JEANRENAUD B: Insulin resistance and hypertension: studies in transgenic hypertensive TGR(mREN-2)27 rats. Am J Physiol 267: R1503-R1509, 1994. https://doi.org/10.1152/ajpregu.1994.267.6.R1503

VOKURKOVÁ M, RAUCHOVÁ H, ŘEZÁČOVÁ L, VANĚČKOVÁ I, ZICHA J: ROS production is increased in the kidney but not in the brain of Dahl rats with salt hypertension elicited in adulthood. Physiol Res 64: 303-312, 2015a. https://doi.org/10.33549/physiolres.933054

VOKURKOVÁ M, RAUCHOVÁ H, ŘEZÁČOVÁ L, VANĚČKOVÁ I, ZICHA J: NADPH oxidase activity and reactive oxygen species production in brain and kidney of adult male hypertensive Ren-2 transgenic rats. Physiol Res 64: 849-856, 2015b. https://doi.org/10.33549/physiolres.933254

WEI Y, CLARK SE, MORRIS EM, THYFAULT JP, UPTERGROVE GM, WHALEY-CONNELL AT, FERRARIO CM, SOWERS JR, IBDAH JA: Angiotensin II-induced non-alcoholic fatty liver disease is mediated by oxidative stress in transgenic $\mathrm{TG}(\mathrm{mRen} 2) 27(\operatorname{Ren} 2)$ rats. J Hepatol 49: 417-428, 2008. https://doi.org/10.1016/j.jhep.2008.03.018

WEI Y, CLARK SE, THYFAULT JP, UPTERGROVE GM, LI W, WHALEY-CONNELL AT, FERRARIO CM, SOWERS JR, IBDAH JA: Oxidative stress-mediated mitochondrial dysfunction contributes to angiotensin IIinduced nonalcoholic fatty liver disease in transgenic Ren2 rats. Am J Pathol 174: 1329-1337, 2009. https://doi.org/10.2353/ajpath.2009.080697

ZICHA J, DOBEŠOVÁ Z, VOKURKOVÁ M, RAUCHOVÁ H, HOJNÁ S, KADLECOVÁ M, BEHULIAK M, VANĚČKOVÁ I, KUNEŠ J: Age-dependent salt hypertension in Dahl rats: fifty years of research. Physiol Res 61 (Suppl 1): S35-S87, 2012. 